\title{
THE FIFTH ANNUAL SOUTHWEST LABOR STUDIES CONFERENCE
}

Reflecting on this two-day conference, held April 20-21, 1979 at the newlybuilt California State University Dominguez Hills Campus in the southern Los Angeles sprawl-and very attractive it was too, the spring flowers outdoing the perennial smell of oil rigs at Long Beach only a few miles away-it seemed to me to be the best of the five annual conferences held by the SWLSC so far. Its business meeting, held on the second day, duly filled in some of the rotating officers' positions. It was also able not only to decide the place and month for next year's conference, which will be held at San Francisco State College in April, 1980, but also for the 1981 meetings, which will be hosted by the University of New Mexico at Albuquerque. Frank Arnold, of the San José branch of the International Association of Machinists, was elected to another term as Secretary-Treasurer; David Brody of the University of California at Davis to another term as vice-president; and Will Scoggins, who runs the Labor Studies Program at El Camino College in the Los Angeles area, to another term as president. These elections reflected the established policy of the SWLSC, which is to maintain a proper balance between academic activists and labor union representatives in the running of the organization, as well as a mixture of different interests in its annual meetings.

And, indeed, it was this mixture of interests, in the labor movement in its formal sense, but also-and to a greater extent than in its previous conventions - in the non-workplace activities of working people, that gave this conference its special value. It also appeared in its declared theme, which was stated as Labor Problems and the Future of Labor. Parts of both these themes were expressed in concern over the present stagnation in the traditional basic industry unions which have been the backbone of the labor movement since the heyday of the CIO, a stagnation which has only been partially compensated for by the growth of white collar unionism. Regret over this decline, and anxiety at its implications for the future, were expressed by various speakers, including expresident Harry Bridges of the International Longshoremen's Union. Bridges, (now retired) opened the conference on Friday with an entertaining, if somewhat rambling, series of reminiscences concerning the halcyon days of his early career in the 1920's and in the CIO. His main theme was the need to return to a rank-and-file controlled labor movement, and to oppose efforts being made by the Carter administration to force labor to take the blame for inflation and other ills, and to fight back much more vigorously than it is presently doing against the various attacks of the political right. Other speakers, in various contexts, also echoed this theme during the two days, one of the few optimistic voices being raised by Dolores Huerta, who appealed for support for the United Farm Worker's current battle in the lettuce fields of California in the rousing language that all of us in the Southwest have come to admire over the last decade and more. 
Turing specifically to the more formal conference sessions, being unable to be at more than one session at once-and there were sometimes three running consecutively, which was perhaps too many for the number of enrolled participants-I have chosen to comment briefly here on those that reflected the specific conference themes. There were other meetings, more conventional but nevertheless valuable, on such topics as labor politics and labor from an international perspective. And we also had a session devoted to reminiscing about the IWW which included, a little incongruously, an interesting comparison by Sam Kushner on efforts which were made to organize farm workers in the Imperial Valley in California in the 1930's, in 1961, and at the present day.

As already indicated, the thematic sessions of the conference fell into two separate categories: those which dealt with earlier and ongoing labor problems, and those which attempted to examine their implications for the future of labor. The first of these two categories brought papers from a wide variety of participants on topics such as the impact of minimun wage legislation on efforts to organize the service industries; the consequences of technological change for the longshore industry, which were especially severe at the San Pedro and Long Beach harbors; and the effects of California's recently adopted Proposition 13 on the quality of its state schools. These sessions followed interesting but fairly predictable lines dealing with monetary shortages, the need for retraining or otherwise protecting the workers in the face of mechanization, and the need to organize teachers into white collar unions.

But it was the other set of thematic sessions, dealing with current and future issues, as well as with more unconventional topics, that proved to be the most interesting. The most dramatic and entertaining of these was entitled "The Waitresses, Hassles and Hard Work: A Three-Dimensional Look at a TwoDimensional Stereotype." This represented an admirable combination of audience involvement and formal presentation, which was achieved by a surprise skit at lunch on the first day when actress-waitresses conducted conversations with would-be clients at various tables, in order to demonstrate the sexual harrassment and other indignities suffered by women in those jobs. Later on this was followed by a more formal session presenting slides which demonstrated these and other problems faced by waitresses, including lower wages than male waiters and the "nurturing" role which is sometimes thrust upon them by long-standing clients of restaurants in which they worked.

Other, not dissimilar sessions included papers by Terry Fee on the impact of Title 7 in recent federal legislation; by Avery Lankford on workplace safety; by Daniel Garrison on the need for worker education in helping assembly line workers understand their jobs; and by Chris A. Jeccinnis on European precedents for employees' participation in management. Yet the session which brought the highest degree of audience participation, and which presented the most carefully integrated combination of topics, was that on "The Blues and Working, How to Get More out of Work." It covered issues of alienation, workers' control of industry, insurance benefits such as maternity leave which more enlightened 
companies are now providing, and several other topics. Paul Bullock, a research economist at UCLA, discussed the increasing use of art and other materials to decorate factory walls as a means of increasing job satisfaction, a development which several speakers from the floor warned against as a new and more sophisticated way of exerting social control over employees. Yank Mojo, former Director of Public Transportation in Aspen, Colorado, presented evidence of similar manipulation occurring in his field. Others linked these fears directly to the need for workers' control in industry.

Altogether, it was an excellent convention.

\section{J. H. M. Laslett}

University of California at Los Angeles

\section{SMITH COLLEGE SYMPOSIUM ON THE "NEW LABOR HISTORY" AND THE NEW ENGLAND WORKING CLASS}

A small group of scholars gathered at Smith College March 4 through 6, 1979, to participate in a symposium on the "new labor history" and the New England working class. The symposium was organized by Herbert Gutman and Stanley Elkins, and it was sponsored by the Smith History Department and American Studies Program, with funding from the Rockefeller Foundation.

The symposium seemed to have been publicized most widely at Smith. There was little publicity at the other area colleges and no public notice of the conference at all outside of western Massachusetts. This lack of publicity meant that the symposium was in effect closed to interested students of labor from other New England colleges and universities. The fact that the conference was held during the week further limited participation to those with an academic work schedule. Area labor unions were not encouraged to send representatives. The papers presented at the symposium raised exciting conceptual issues and the discussions were provocative and wide-ranging. But the potential of the conference to influence future questions and directions of New England labor history research was undermined by the failure to bring together a wider public audience.

In her opening presentation on the new labor history, Joan Scott speculated on the effects of the New Left critique of organization, the sociological challenge to modernization theory, and quantitative methodology on the formulations of questions and the direction of research in this field. In her comments, Jill Conway suggested some of the ways in which women's history and family history must force a revision of the traditional categories of labor history. Herbert Gutman emphasized that ethnicity and class cannot be separated in the search for the origins of consciousness. 